\title{
Occurrence of multidrug resistant (MDR) Campylobacter species isolated from retail chicken meats in Selangor, Malaysia and their associated risk factors
}

\author{
Muhammad Jalo Ibrahim ${ }^{1,5}$, Saleha Abdul-Aziz ${ }^{1 *}$, Asinamai Athliamai Bitrus ${ }^{1,4}$, Dauda Goni Mohammed1,3,5, Jalila \\ $\mathrm{Abu}^{2}$, Siti Khairani Bejo', Mohamed Abdelrahman Mohamed ${ }^{1}$, Mohamed Yousif Ibrahim Mohamed ${ }^{1}$ \\ ${ }^{1}$ Department of Pathology and Microbiology, Faculty of Veterinary Medicine, University Putra Malaysia, 43400 UPM \\ Serdang, Selangor, Malaysia. \\ ${ }^{2}$ Department of Veterinary Clinical Studies, Faculty of Veterinary Medicine, University Putra Malaysia, 43400 UPM \\ Serdang, Selangor, Malaysia. \\ ${ }^{3}$ Unit of Biostatistics and Research Methodology, School of Medical Sciences, Health Campus, Universiti Sains \\ Malaysia, 16150 Kubang Kerian, Kelantan, Malaysia. \\ ${ }^{4}$ Research Unit in Microbial food safety and Antimicrobial resistance, Department of Veterinary Public Health, Faculty of \\ Veterinary Sciences, Chulalongkorn University, 10330 Pathumwan, Bangkok, Thailand. \\ ${ }^{5}$ Veterinary Service Department, Ministry of Agriculture and Environment, Damaturu Yobe State Nigeria. \\ Email: aasaleha@yahoo.com
}

Received 6 September 2017; Received in revised form 20 December 2017; Accepted 15 February 2018

\begin{abstract}
Aims: Campylobacter infection is one of the leading bacterial food-borne illness and most frequently reported in humans in developed countries. This study was designed to determine the prevalence of multidrug resistant (MDR) Campylobacter and the risk factors associated with their occurrence in broiler chicken meat retailed in markets.

Methodology and results: A total of 210 samples consisting of 140 chicken meat and 70 swabs from weighing scales and cutting boards were collected. Isolates were cultured by passive filtration method, identified by biochemical tests and confirmed using PCR assay. Thirty-two (32/210) 15.2\% were positive for Campylobacter of which (25/210) 11.9\%, (6/210) $2.9 \%$ and (1/210) $0.5 \%$ were Campylobacter jejuni, C. coli and C. upsaliensis respectively. The isolates showed high resistance to ampicillin (62.5\%), enrofloxacin (56.3\%) and nalidixic acid $(50.0 \%)$, while only $3.1 \%$ were resistant to streptomycin. Multidrug resistant isolates (resistance to at least one antibiotics in three classes or more) was high at $71.9 \%$. The risk factors significantly $(p<0.05)$ associated with Campylobacter contamination on chicken's meat included poor workers hygiene \{OR: 5.250 (95\% Cl: 0.988-27.895)\}, wearing improper work attire \{OR: 2.700 (95\% Cl: $1.144-$ $6.374)\}$, poor protective equipment $\{\mathrm{OR} 38.50$ (95\% Cl: 2.915-508.463)\}, poor environment/stall hygiene \{OR 44.00 (95\% Cl: 2.193-882.66)\}, and using tiled counter top surface \{OR 6.667 (95\% Cl: 0.597-74.506).

Conclusion, significance and impact of study: The finding of this study affirmed that lack or poor work hygiene, unclean environmental stall and protective equipment are associated with high occurrence of multidrug resistant Campylobacter species isolated from chicken meat
\end{abstract}

Keywords: Campylobacter, chicken, multidrug resistance, risk factors

\section{INTRODUCTION}

Campylobacter is one of the leading causes of foodborne diarrhea illness in the developed countries and a significant public health concern worldwide (Goni et al., 2017). In humans, infections caused by Campylobacter jejuni and $C$. coli are well known and transmission is generally through water, milk, and food animals (Huang et al., 2009). Retail meat products, particularly poultry meat, have been frequently implicated as sources of infection, and are considered a major risk factor for
Campylobacteriosis in humans (Meldrum and Wilson, 2007). The pathogenicity and survivability of Campylobacter strains is enhanced by the expression of the antibiotic resistance characteristics and distinct virulence determinants (Young et al., 2007; Luo et al., 2005).

In humans, poultry meat is considered the principal source of Campylobacter infection, with infection acquired through fecal-oral route. In the United Kingdom, Food Standards Agency (FSA) (EFSA, 2009) reported a 62.5\% prevalence of $C$. in poultry meat. Similarly, several studies 
have reported the occurrence of $C$. jejuni in poultry and chickens (Hussain et al., 2007; Stoyanchev et al., 2007; Little et al., 2008). Berrang et al. (2004), illustrated that during processing, Campylobacter from the intestinal tracts could contaminate the surface of poultry carcasses. Cross contamination can also occur during preparation in the home kitchen from the raw meat products which can contaminate other foods and kitchen utensils. Crosscontamination to other ready-to-eat products and handling of contaminated raw meats are some of the possible risk factors associated with human Campylobacter and Salmonella infection (Smerdon et al., 2001). Consumption of under-cooked poultry meat can lead to sporadic human incidence, while outbreaks are usually related with raw milk (Denis et al., 2011). Foods prepared in restaurants have been associated in nearly half of the total sporadic Campylobacter illnesses in the United States (Friedman et al., 2004).

It has been reported that the use of antibiotic in animals intended for food has led to the development of antibiotic resistance in E. coli, Salmonella, Enterococcus and Campylobacter in animals, which can be transferred to humans through the food chain (Akinbowale et al., 2006). Campylobacteriosis is an important foodborne zoonotic disease. In the US, Campylobacter isolates resistant to fluoroquinolones (FQ) in human are consistently increasing due to the widespread use of the drug in animals and poultry production (Price et al., 2005; Oliver et al., 2011). Multidrug resistance (MDR) is frequently observed in food borne pathogens. MDR in Campylobacter have been reported in a number of studies; for instance, Zoran et al. (2010) in Serbia reported that $10 \%$ of $C$. jejuni and $16.3 \%$ of $C$. coli were resistant to three or at least one in three classes of antibiotics. Other studies, reported that multidrug resistance was common in C. coli isolates compared to C. jejuni (Uaboi et al., 2012; Tambur et al., 2010; Englen et al., 2007). Thus, this study was designed to determine the occurrence of multidrug resistant (MDR) Campylobacter and the possible risk factors associated with their occurrence in broiler chicken meat retailed in markets in Selangor.

\section{MATERIALS AND METHODS}

\section{Samples collection}

A total of 210 samples consisting of 140 chicken meat parts and 70 weighing scales and cutting boards that were swabbed randomly in seven different selected markets in Selangor. Each meat sample was placed in a sterile plastic bag and each swab sample of weighing scale and cutting board was placed in a sterile bottle containing 2 $\mathrm{mL}$ of Bolton Selective Enrichment Broth (Oxoid) supplemented with Bolton Antibiotic Supplements (Oxoid SR0208E) and 5\% defibrinated lysed horse blood. The samples were kept in a box with ice packs and transported to the laboratory and processed within 2-4 $\mathrm{h}$ post sampling.

\section{Isolation and identification of Campylobacter}

The isolation of Campylobacter in broiler chickens was carried out using the Cape Town Protocol developed by Le Roux and Lastovica (1998). Twenty-five grams of each meat sample was taken, homogenized, enriched in a broth and incubated at $42{ }^{\circ} \mathrm{C}$ for $48 \mathrm{~h}$ under microaerophilic condition generated using CampyGen gas pack (Oxoid $\mathrm{CN} 0025 \mathrm{~A}$ ). A volume of $200 \mu \mathrm{L}$ each of enriched mixture were dropped onto a membrane filter of $0.65 \mu \mathrm{m}$ pore-size cellulose nitrate and of $47 \mathrm{~mm}$ diameter (Milipore, Sartorius Stedim, Biotech, Goettingen Germany) which was placed onto Colombia Blood Agar (CBA) (Oxoid) plate. Passive filtration was set for $45 \mathrm{~min}$ before incubation under microaerophilic condition at $42{ }^{\circ} \mathrm{C}$ for 48 h. Presumptive Campylobacter colonies were selected and identified on the basis of colony morphology, motility using wet mounts, cellular morphology from Gram staining and biochemical tests which included: hippurate hydrolysis, indoxyl-acetate hydrolysis, urease, and oxidase and catalase tests.

\section{PCR confirmation of Campylobacter species}

Bacterial DNA was extracted by a crude boiling method. A bacterial suspension of fresh overnight culture was prepared in a $1.5 \mathrm{~mL}$ Eppendorf tube (Eppendorf, Australia) containing $1000 \mu \mathrm{L}$ of sterile distilled water. The suspension was incubated for $10 \mathrm{~min}$ in dry bath at $94^{\circ} \mathrm{C}$, and allowed to cool at room temperature $\left(25^{\circ} \mathrm{C}\right)$. The bacterial suspension was centrifuged for $3 \mathrm{~min}$ at 13,000 rpm and the supernatant was used DNA template.

Multiplex PCR (mPCR) was performed using specific primers, appropriate cycling conditions and standardized positive controls (C. jejuni (ATCC 29428), C. coli (ATCC 33559) and C. upsaliensis (CCUG 14913T) as described by Yamazaki-Matsune et al. (2007) (Table 1). The reaction mixture was performed in a $50 \mu \mathrm{L}$ reaction volume containing $25 \mu \mathrm{L}$ of TopTaq Master Mix (QIAGEN), $1 \mu \mathrm{L}$ $(10 \mathrm{mM})$ of each forward and reverse primer (Table 1), 5 $\mu \mathrm{L}$ of Coral load (QIAGEN), $4 \mu \mathrm{L}$ of DNA templates and 14 $\mu \mathrm{L}$ of RNase-free water (QIAGEN). The reaction mixtures were amplified in a thermal cycler (Eppendorf) with the following cycling parameters: pre-denaturation at of $95^{\circ} \mathrm{C}$ for $2 \mathrm{~min}$, followed by 25 cycles of denaturation at $95^{\circ} \mathrm{C}$ for $30 \mathrm{sec}$, annealing at $58^{\circ} \mathrm{C}$ for $2 \mathrm{~min}$ and elongation at $72{ }^{\circ} \mathrm{C}$ for $1 \mathrm{~min}$, ending with a final elongation at $72{ }^{\circ} \mathrm{C}$ for $7 \mathrm{~min}$.

Amplified PCR products were resolved in a $3 \%$ agarose gel $(\mathrm{w} / \mathrm{v})$ (Promega, USA) prepared in $1 \mathrm{X}$ TBE buffer contains Tris-Borate-EDTA (TBE) solution and (89 $\mathrm{mM}$ Tris Base, $89 \mathrm{mM}$ Boric acid, 2 mM EDTA, pH 8.3) at $100 \mathrm{~V}$ for $90 \mathrm{~min}$. The gel was visualized under transilluminator UV with the aid of Alpha Imager (Bio-Rad) after staining in ethidium bromide for $2 \mathrm{~min}$ and de-stained in distilled water for 30 min (Figure 1). 
Table 1: Primers used for the amplification of Campylobacter genes.

\begin{tabular}{|c|c|c|c|c|}
\hline Species & $\begin{array}{l}\text { Size } \\
\text { (bp) }\end{array}$ & Target gene & Oligonucleotide sequence ( $\left.5^{\prime}-3^{\prime}\right)$ & References \\
\hline $\begin{array}{l}\text { Genus } \\
\text { Campylobacter }\end{array}$ & 816 & 16S rRNA & $\begin{array}{l}\text { C412F 5'-GGA TGA CAC TTT TCG GAG C-3' } \\
\text { C1228R 5'-CAT TGT AGC ACG TGT GTC-3' }\end{array}$ & Linton et al. (1996) \\
\hline C. coli & 501 & ceuE gene & $\begin{array}{l}\text { F -5'-ATG AAA AAA TAT TTA GTT TTT GCA-3' } \\
\text { R-5'-ATT TTA TTA TTT GTA GCA GCG-3' }\end{array}$ & Gonzalez et al. (1997) \\
\hline C. upsaliensis & 86 & IpXA & $\begin{array}{l}\text { CU61F -5'-CGA TGA TGT GCA AAT TGA AGC-3' } \\
\text { CU146R- 5'-TTC TAG CCC CTT GCT TGA TG-3' }\end{array}$ & Klena et al. (2004) \\
\hline C. Jejuni & 323 & hip & $\begin{array}{l}\text { CJF-5'-ACT TCT TTA TTG CTT GCT GC-3' } \\
\text { CJR-5'-GCC ACA ACA AGT AAA GAA GC-3' }\end{array}$ & Wang et al. (2002) \\
\hline
\end{tabular}

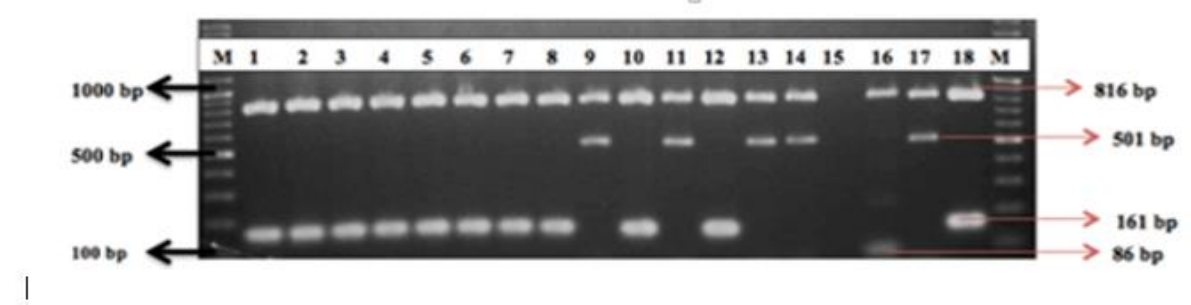

Lane M: 100 bp molecular DNA marker, Lane 1-14 Campylobacter isolates, Lane 15: Negative control, Lane 16: C. upsaliensis CCUG 14913, Lane 17: C. coli ATCC 33559, Lane 18: C. jejuni ATCC 29428

Figure 1: Electropherogram showing PCR detection of Campylobacter isolates.

\section{Antibiotic susceptibility test}

The antibiotic susceptibility test was performed using disc diffusion method as described by the Clinical Laboratory Standard Institute (CLSI) (2014). Campylobacter isolates were tested against 12 antibiotics from different classes of veterinary critically important antibiotics (OIE, 2015) which included ciprofloxacin (cip), $5 \mu \mathrm{gg}$; ampicillin (Amp), $10 \mu \mathrm{g}$; tetracycline (Te), $30 \mu \mathrm{g}$; erythromycin (E), $15 \mu \mathrm{g}$; gentamicin (Cn), $10 \mu \mathrm{g}$; cefotaxime (ctx), $30 \mu \mathrm{g}$; penicillin $G(P), 10 \mu \mathrm{g}$; streptomycin $(\mathrm{S}), 10 \mu \mathrm{g}$; nalidixic acid (Na), $30 \mu \mathrm{g}$; enrofloxacin (Enr), $5 \mu \mathrm{g}$; amoxicillinclavalunic acid (Amc), $10 \mu \mathrm{g}$ and trimetophrimsulfamethoxazole (sxt) $25 \mu \mathrm{g}$. Isolates were classified as sensitive, intermediate and resistant using zone diameter breakpoints as in CLSI (2014).

\section{Statistical analysis}

Chi-square test $(x 2)$ was used to determine the proportion of Campylobacter species resistant to each tested antibiotic using IBM SPSS version 21.

\section{Risk factor analysis}

Descriptive analysis, chi-square $(X 2)$ and univariate logistic regression for risk factor analysis using IBM SPSS version 21 were performed. Two variables, how the meat was displayed and use of disinfectant were excluded in the univariate risk factor analysis because all the meat was displayed without putting ice and disinfectant was not using to clean the stall as such there was no variation and could not be compared. A conditional logistic model was used for univariate analysis, and exposures with $P<0.05$ were considered significant. For both univariate logistic regression and chi-square, continuous variables were dichotomized, and the median value was chosen as the breakpoint. Variables were constructed by combining multiple items from the questionnaire.

\section{Questionnaire design}

The questionnaire used in this study was designed to assess the factors that are associated with the occurrence of Multidrug resistant (MDR) Campylobacter at selected retails outlet within Selangor namely; Semenyih wet market, Sentul wet market, Pasar Raya awam Serdang, Pasar Borong Selangor, Chow-kit wet market, Pasar Awam Bangi and Pasar awam Banting. The targeted respondents were chicken meat sellers. The consent of each respondent was sort for, before they were given the questionnaire to fill with the aid of a Bahasa Melayu language translator. The questionnaire was designed to take about $15 \mathrm{~min}$ to complete Table 2 . 


\section{RESULTS}

A total of $32(15.2 \%)$ Campylobacter were isolated, 28 $(20 \%)$ were from chicken meat and $4(5.7 \%)$ from weighing scales and cutting boards (Table 3 ). Three (3) species of Campylobacter were identified, namely $C$ jejuni, C. coli and C. upsaliensis at $11.9 \%, 2.9 \%$ and $0.5 \%$ respectively. Campylobacter isolates showed high resistance to ampicillin, enrofloxacin and nalidixic acid at $62.5 \%, 56.3 \%$ and $50.0 \%$ respectively, while the least resistance was to streptomycin at $3.1 \%$. At species level, C. jejuni showed exceptionally high resistance to all 12 antibiotics tested. Resistance towards streptomycin was observed in all the isolates (100\%). Eighty-four (84.6\%) of $C$. jejuni isolates were resistant to cefotaxime, while more than $60 \%$ of $C$. jejuni isolates were resistant to Erythromycin (76.9\%), Penicillin G $(73.3 \%)$, Nalidixic acid $(76.5 \%)$, Ciprofloxacin (70\%), Tetracycline and Trimethoprim-sulfamethoxazole (71.4\%), Gentamicin (75\%), Enrofloxacin (68.4\%), Ampicillin (76.2\%), and Amoxicillin (63.6\%) respectively Table 4 . Similarly, all $C$. coli isolates showed resistance towards all the antibiotic tested with the exception of streptomycin.
Table 3: Prevalence of Campylobacter in chicken meat and on cutting board and weighing scale in market.

\begin{tabular}{|c|c|c|}
\hline \multirow[b]{2}{*}{$\begin{array}{l}\text { Location of the wet } \\
\text { markets }\end{array}$} & \multicolumn{2}{|c|}{ Number of positive samples (\%) } \\
\hline & $\begin{array}{c}{ }^{*} \text { Chicken meat } \\
\mathrm{n}(\%)\end{array}$ & $\begin{array}{c}{ }^{* \star} \text { Cutting board and } \\
\text { weighing scale } \\
(\%)\end{array}$ \\
\hline $\begin{array}{l}\text { Semenyih wet } \\
\text { market }\end{array}$ & $1 / 20(5.0 \%)$ & $0 / 10(0 \%)$ \\
\hline Sentul wet market & $0 / 20(20.0 \%)$ & $0 / 10(0 \%)$ \\
\hline $\begin{array}{l}\text { Pasar Raya Awam } \\
\text { Serdang }\end{array}$ & $4 / 20(20.0 \%)$ & $3 / 10(30.0 \%)$ \\
\hline $\begin{array}{l}\text { Pasar Borong } \\
\text { Selangor }\end{array}$ & $5 / 20(25.0 \%)$ & $0 / 10(0 \%)$ \\
\hline $\begin{array}{l}\text { Chow-Kit wet } \\
\text { market }\end{array}$ & $4 / 20(20.0 \%)$ & $1 / 10(10.0 \%)$ \\
\hline Pasar Awam Bangi & $8 / 20(40.0 \%)$ & $0 / 10(0 \%)$ \\
\hline $\begin{array}{l}\text { Pasar Awam } \\
\text { Banting }\end{array}$ & $6 / 20(30.0 \%)$ & $0 / 10(0 \%)$ \\
\hline Overall total & $28 / 140(20.0 \%)$ & $4 / 70(5.7 \%)$ \\
\hline
\end{tabular}

${ }^{*}$ Keel, wing, drumstick and breast meat included skin at 20 each / market

** Swabs of cutting board and weighing scale at 10 each

Table 2: Definition and description of exposure variables of meat handling practices associated with the occurrence of Campylobacter in stalls in selected market.

\begin{tabular}{|c|c|c|}
\hline Variables & \multicolumn{2}{|c|}{ Description scores and categorization } \\
\hline 1.Wearing work-attire at the market & $\begin{array}{l}\text { 1. Yes } \\
\text { 2. No }\end{array}$ & \\
\hline 2. Workers hygiene & $\begin{array}{l}\text { Good (All } 3 \text { scores) } \\
\text { Fair ( } 2 \text { scores) } \\
\text { Poor ( } 1 \text { or } 0 \text { score) }\end{array}$ & $\begin{array}{l}\text { Clean cloth }=1 \\
\text { Clean apron }=2 \\
\text { Clean gloves }=3\end{array}$ \\
\hline 3. Using protective equipment & $\begin{array}{l}\text { Good (All } 3 \text { scores) } \\
\text { Fair ( } 2 \text { scores) } \\
\text { Poor ( } 1 \text { or } 0 \text { score) } \\
\text { Others }\end{array}$ & $\begin{array}{l}\text { Hand gloves }=1 \\
\text { Boot }=2 \\
\text { Apron }=3\end{array}$ \\
\hline 4. Stall environment hygiene & $\begin{array}{l}\text { Good (All } 3 \text { scores) } \\
\text { Fair ( } 2 \text { scores) } \\
\text { Poor ( } 1 \text { or } 0 \text { score) }\end{array}$ & $\begin{array}{l}\text { Clean counter surface }=1 \\
\text { Clean floor }=2 \\
\text { No much flies }=3\end{array}$ \\
\hline 5. Type of counter - top surface & $\begin{array}{l}\text { Tiles } \\
\text { Wooden table } \\
\text { Stainless steel } \\
\text { Others... }\end{array}$ & \\
\hline 6.Source of water for washing meat and counter surface & $\begin{array}{l}\text { Collected in container } \\
\text { Direct from the tap } \\
\text { Others... }\end{array}$ & \\
\hline 7. Placing ice on the carcasses & $\begin{array}{l}\text { Yes } \\
\text { No }\end{array}$ & \\
\hline 8. Type of Cutting board & $\begin{array}{l}\text { Wood } \\
\text { Plastic } \\
\text { Others... }\end{array}$ & \\
\hline 9. Use of disinfectants to clean stall premise & $\begin{array}{l}\text { Yes } \\
\text { No }\end{array}$ & \\
\hline 10. Mode of meat display on the counter & $\begin{array}{l}\text { Open without ice pack } \\
\text { Open with ice pack } \\
\text { Others... }\end{array}$ & \\
\hline
\end{tabular}


Table 4: Percentage of antibiotic resistance in Campylobacter isolates.

\begin{tabular}{|c|c|c|c|c|c|c|c|c|c|c|c|c|}
\hline \multirow[t]{2}{*}{ Antibiotics } & \multicolumn{12}{|c|}{ \% Antibiotic Resistance } \\
\hline & E15 & $\mathrm{P} 10$ & $\mathrm{Na30}$ & cxt30 & $\mathrm{S} 10$ & cip5 & Te30 & sxt25 & cn10 & en5 & Amp10 & Am30 \\
\hline C. upsaliensis & 7.7 & 6.7 & 5.9 & 0 & 0 & 10 & 7.1 & 14.3 & 0 & 5.3 & 4.8 & 9.1 \\
\hline $\begin{array}{c}\text { C. coli } \\
\text { C. jejuni }\end{array}$ & $\begin{array}{l}15.4 \\
76.9\end{array}$ & $\begin{array}{c}20 \\
73.3\end{array}$ & $\begin{array}{l}17.6 \\
76.5\end{array}$ & $\begin{array}{c}25 \\
84.6\end{array}$ & $\begin{array}{c}0 \\
100\end{array}$ & $\begin{array}{l}20 \\
70\end{array}$ & $\begin{array}{l}21.4 \\
71.4\end{array}$ & $\begin{array}{l}14.3 \\
71.4\end{array}$ & $\begin{array}{l}25 \\
75\end{array}$ & $\begin{array}{l}26.3 \\
68.4\end{array}$ & $\begin{array}{c}19 \\
76.2\end{array}$ & $\begin{array}{l}27.3 \\
63.6\end{array}$ \\
\hline Total & 37.5 & 43.8 & 50 & 37.5 & 3.1 & 28.1 & 43.8 & 21.9 & 12.5 & 56.3 & 62.5 & 34.4 \\
\hline
\end{tabular}

trimethoprim-sulfamethoxazole; cn: gentamicin; en: enrofloxacin; Amp: ampicillin; Am: amoxicillin

Additionally, high resistance towards amoxicillinclauvalunic, enrofloxacin, ciprofloxacin and gentamicin at $27.3 \%, 26.3 \%$ and $25 \%$ was observed. This finding is in agreement with the report of Tang et al. (2009). In C. upsaliensis only $14.3 \%$ of isolates showed resistance towards the antibiotics sulphamethoxazole-trimethoprim while none of the isolates were resistant cefotaxime, streptomycin and gentamycin respectively (Table 4). However, C. upsaliensis isolates were resistant Erythromycin (7.7\%), Penicillin G $(6.7 \%)$, Nalidixic acid (5.9\%), Ciprofloxacin (10\%), Tetracycline (7.1\%), Enrofloxacin (5.3\%), Ampicillin (4.8\%), and Amoxicillin $(9.1 \%)$ respectively (Table 4$)$.

All isolates showed resistance to at least one antibiotic; the most was to 4 - 5 antibiotics at $15.6 \%$. The MDR (resistant to at least one antibiotic, in three or more classes) was 71.9\% (Figure 2). Twenty-three (23) different antibiotic resistance patterns were detected in nine (9) antibiogroups (that is groups showing the number and types of antibiotics to which each isolate was resistant). The most common multidrug resistance profile for Campylobacter isolates was to 4 (TeAmcEnrAmp) and 5 (EPTeCtxAmp) classes of antibiotics at $15.6 \%$ each (Figure 2).

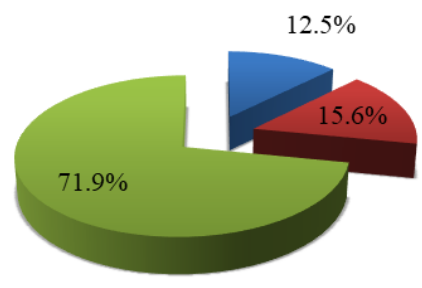

$$
\begin{aligned}
& \text { Isolates susceptible to } \\
& \text { all antibiotics } \\
& \text { Isolates resistance to } \\
& 1-2 \text { classes of } \\
& \text { antibiotics } \\
& \text { Isolates resistance to } \\
& 3 \text { or more classes of } \\
& \text { antibiotics (MDR) }
\end{aligned}
$$

Figure 2: Percentage of MDR Campylobacter on chicken meat, weighing scales and cutting boards.

This study identified five (5) risk factors for Campylobacter contamination on chicken meat in the market that, if taken together, might account for most contamination and although relevant but not statistically significant was poor work hygiene (OR 5.250, Cl 0.98827.895, $p=0.05$ ). This is because, there is 5 times likelihood of chicken meat contamination with Campylobacter as a result of poor hygiene. Those factors that were significant were without using proper working attire (OR 2.7, $\mathrm{Cl} 1.144-6.374, p=0.033$ ), using poor protective equipment (OR $38.50, \mathrm{Cl} 2.915-508.463$, $p=0.006$ ), poor stall hygiene (OR 44.00 , Cl 2.193$882.66, p=0.013$ ) and titled counter top surface (OR 6.1, Cl 1.198-31.164, $p=0.029$ ) as shown in (Table 5). This means that the likely hood of contamination with Campylobacter as a result of the lack of using protective clothing $\mathrm{OR}=38.5$ and poor stall hygiene $\mathrm{OR}=44.0$ is higher than the likely hood of contamination as a result of using proper working attire $\mathrm{OR}=2.7$ and titled counter top surface $\mathrm{OR}=6.1$.

\section{DISCUSSION}

Campylobacter contamination is found more frequently in chicken meat compared to other meat (Abu-Madi et al., 2016). Carcass contamination occurred mostly through cross contamination during slaughtering and dressing processes. According to Herman et al. (2003), it is difficult for any slaughterhouse to avoid carcass contamination with foodborne pathogens. Equipment and surfaces can be sources of direct contamination when they have not been effectively cleaned or remained wet between cleaning and subsequent usage (Evans et al., 2004). Cross-contamination of bacteria such as Salmonella and Campylobacter during food preparation in the kitchens or any processing plants is considered a risk factor for human exposure to these foodborne pathogens. An important route of crosscontamination being transfer of bacteria from contaminated chicken carcasses via cutting boards or other unwashed surfaces to ready-to-eat foods (Kusumaningrum et al., 2004). In this study however, there was an association $(p=0.05)$ between poor hygiene and presence of Campylobacter on the chicken meat in the market. Poor waste disposal and unsatisfactory sanitation were five times more likely to cause poultry meat to be contaminated with Campylobacter than those with good hygiene. The condition of stall hygiene can predict the occurrence of cross contamination with Campylobacter. Poor stall hygiene was 44 times likely to cause contamination of the meat compared to good stall hygiene and this association was statistically significant at $p=0.013$. Furthermore, it was observed that the risk of contamination was high when the workers wore dirty 
Table 5: Univariate logistic regression for risk factors associated with Campylobacter isolates in markets.

\begin{tabular}{|c|c|c|c|c|c|c|}
\hline \multirow[t]{2}{*}{ Risk Factors } & \multirow[t]{2}{*}{ Category } & \multirow[t]{2}{*}{ Prevalence (\%) } & \multirow[t]{2}{*}{$P$-value } & \multirow[t]{2}{*}{ Odd ratio } & \multicolumn{2}{|c|}{ 95\% Confidence interval } \\
\hline & & & & & Lower & Upper \\
\hline \multirow[t]{3}{*}{ Workers hygiene } & Good & 19.0 & REF & NA & NA & NA \\
\hline & Fair & 23.8 & 0.266 & 2.917 & 0.442 & 19.234 \\
\hline & Poor & 57.1 & 0.052 & 5.250 & 0.988 & 27.895 \\
\hline \multirow[t]{2}{*}{ Wearing working attire } & Yes & 23.8 & REF & NA & NA & NA \\
\hline & No & 76.2 & $0.033^{*}$ & 2.700 & 1.144 & 6.374 \\
\hline \multirow[t]{3}{*}{ Wearing protective equipment } & Good & 4.8 & REF & NA & NA & NA \\
\hline & Fair & 42.9 & $0.036^{*}$ & 12.60 & 1.186 & 133.899 \\
\hline & Poor & 52.4 & $0.006^{*}$ & 38.50 & 2.915 & 508.463 \\
\hline \multirow[t]{3}{*}{ Stall hygiene } & Good & 4.8 & REF & NA & NA & NA \\
\hline & Fair & 42.9 & 0.253 & 4.00 & 0.371 & 43.139 \\
\hline & Poor & 52.4 & $0.013^{*}$ & 44.00 & 2.193 & 882.66 \\
\hline \multirow[t]{3}{*}{ Type of counter surface } & Stainless steel & 19.0 & REF & NA & NA & NA \\
\hline & Tiles & 28.6 & 0.123 & 6.667 & 0.597 & 74.506 \\
\hline & Wood & 52.4 & $0.029^{*}$ & 6.111 & 1.198 & 31.164 \\
\hline \multirow[t]{2}{*}{ Source of water } & Tap & 14.3 & REF & NA & NA & NA \\
\hline & Container & 85.7 & 0.259 & 1.167 & 0.980 & 1.389 \\
\hline
\end{tabular}

*Significant $(p<0.05)$, NA: Not applicable, REF Reference category.

clothing while working in the markets. These results corroborated the findings of Mensah et al. (2000) and Caballero et al. (1988) who identified personnel as mechanical vehicles of Salmonella and other zoonotic bacteria causing cross-contamination from raw chicken, vegetables, or environment via utensils or other tools or equipments (Jacobs-Reistma, 1997).

Another significant association $(p=0.033)$ observed, was between those without proper work attire, which were three times likely to contaminate the meat and equipment than those with good work attire. Those with fair and poor protective equipment were 13 and 38 times more likely respectively to be exposed or contaminated the meat and equipment than those with a good protective equipment and this association was significant at $p=0.036$ and $p=0.006$ respectively. It is generally accepted that the hands of food handlers are an important vehicle of cross contamination on food and that improved personal hygiene and good hand hygiene can prevent the spread of pathogenic bacteria (Sneed et al., 2004; Lues and Van Tonder, 2007). This finding highlights the important role of good hygienic measures in the prevention of food contamination. Hence there is the need for regular cleaning with water in order to minimize the unavoidable environmental contamination. The protective effects of using stainless steel equipment was six times less likely to contaminate the chicken meat and equipment in comparison with wood counter top surface. This finding suggested the use of stainless steel is vital to reduce carcass contamination which is agreeable with a study by Kusumaningrum et al. (2002) who inoculated stainless steel surfaces with a test suspension of $C$. jejuni and noticed a three-log reduction in the first $30 \mathrm{~min}$. After $4 \mathrm{~h}$ of incubation, no
Campylobacter could be recovered. Cogan et al. (2002) computed cross-contamination in a study in which the volunteers were asked to cut a naturally Campylobactercontaminated whole raw chicken carcass into pieces; the study found $85 \%$ of hands and $80 \%$ of cutting boards made up of wood were contaminated with Campylobacter. A qualitative cross-contamination study from the Netherlands indicated that $C$. jejuni were conveyed from raw chicken products to cutting boards, plates, and especially to hands (De Boer and Hahne', 1990). It is considered that cross-contamination and not undercooking is the dominant route of exposure to humans (Nauta et al., 2009). Two other risk factors which could also potentially accounted for Campylobacter contamination in meat and equipment included: how the meat is displayed and use of disinfectant to clean the stall were not included in the univariate risk factor analysis because there was no difference in the variables. To decrease carcass contamination, decontamination procedures can be instituted which could be physical or use of chemical to decrease the microbial load. Dipping can reduce contamination of carcasses with Campylobacter or spraying of carcasses using chlorinated water, acidified sodium chlorite (ASC) or acetic or lactic acids. Trisodium phosphate (TSP) has also been widely used, but due to processing and environmental problems its use is now minimal. It is widely assumed that harvesting or gradual depopulation is a significant risk factor for flock colonization.

The high prevalence of Campylobacter in raw poultry meat found in this study was similar with other studies (Moore et al., 2002; Denis et al., 2001). Due to the high concentration of Campylobacter in the intestines, in 
particular the caeca, chicken carcasses may become contaminated at the surface during processing as a result of contamination. Carcasses from Campylobacter negative broilers can become contaminated through contaminated equipment when they are processed after a positive Campylobacter flock (Frediani-Wolf and Stephan, 2003). However, this contamination usually results in a lower concentration of bacteria at the surface compared to carcasses from colonized chickens and reported to have a negligible impact on the risk for humans compared to products from Campylobacter positive flocks (Rosenquist et al., 2003). The high occurrence of Campylobacter during processing may lead to contaminated poultry carcasses in the retail market. If the initial carcasses are contaminated with Campylobacter, the contact surfaces in the processing environment become contaminated and contribute to cross-contamination to poultry meat. Therefore, starting with good microbiological quality poultry carcasses should reduce the contamination level of processed poultry products.

There is a limited option in the use of antibiotics for the treatment of Campylobacter infection, and resistance towards those antibiotics increase the need of an alternative antibiotics (Hong et al., 2007). The crossresistance among Campylobacter strains to enrofloxacin, ciprofloxacin and other fluoroquinolones might also explain the increasing number of resistance toward fluoroquinolones (Jacobs-Reitsma et al., 1994; Hong et al., 2007). Low-level resistance to aminoglycosides (streptomycin) generally can be attributed to the intermittent usage of this group of antibiotics in the poultry either at prophylactic or therapeutic level due to its intramuscular route of administration, which may be impracticable for largescale application (Rodrigo et al., 2007). Since erythromycin is the drug of choice for the treatment of Campylobacter infections, the resistance to this antibiotic, especially among strains isolated from food, should be a cause for special concern. In this study, majority of Campylobacter strains (70.0\%) were resistant to one or more antibiotics. Furthermore, most of the isolates $(50.0 \%)$ showed resistance to two or more different classes of antibiotics and this percentage was higher than that reported by other authors (Andersen et al., 2006; Sallam 2007; Rozynek et al., 2008). The findings above is in agreement with the documentation of Health Action International Asia Pacific (HAIAP) (2013) on the use of antibiotics in animals in Malaysia. The report showed that the mostly commonly used antibiotics in poultry farms in Malaysia are Erythromycin, Ampicillin, Amoxicillin, gentamycin and enrofloxacins. One $C$. coli isolate was resistant to four classes of antibiotics including fluoroquinolones and macrolides. Most of Campylobacter species (62.5\%) isolated in this study were resistant to ampicillin. Seventy-six-point two percent $(76.2 \%)$ of $C$. jejuni, $19.0 \%$ of C. coli and $4.8 \%$ C. upsaliensis isolated from chicken meat were found resistant to ampicillin. The result of this study was similar to the study by Sáenz et al. (2000) who reported $47.4 \%$ of C. jejuni and $90 \%$ of C. coli were resistant to ampicillin. A lower resistance was reported by Miflin et al. (2007) who found $17.6 \%$ of $C$. jejuni and $14.8 \%$ of $C$. coli were resistant to ampicillin. The high antibiotic resistance in this study may possibly be due to inappropriate use of antibiotics at sub-therapeutic doses in broilers for prophylaxis and growth promotion (Saleha, 2002; Olah et al., 2006).

\section{CONCLUSION}

Five risk factors for high antibiotic resistant Campylobacter contamination of poultry carcasses were identified. Most of the risk factors were associated with hygienic practices which called for good disinfection and hygienic practices by the workers. To enhance the hygienic level of retail outlets, retailers, managers and staff must be informed and sensitized about the risk of this bacteria especially with regards to food safety and also proper washing of contaminated hands, knives and chopping boards before and after meat handling is vital. The presence of high MDR Campylobacter species could compromise human health. Therefore, there is a need to further educate and emphasize among farmers the need to observe good husbandry practices and prudent use of antibiotics to reduce the menace of antibiotic resistance and among chicken meat stall owners to observe good hygienic practices.

\section{ACKNOWLEDGEMENT}

The authors wish to acknowledge the staff of Veterinary Public Health Laboratory, and Department of Pathology and Microbiology, Faculty of Veterinary Medicine for their assistance.

\section{REFERENCES}

Abu-Madi, Marawan., Behnke, J. M., Sharma, A., Bearden, R. and Al-Banna, N. (2016). Prevalence of virulence/stress genes in Campylobacter jejuni from chicken meat sold in Qatari retail outlets. PloS ONE 11, e0156938.

Akinbowale, O. L., Peng, H. and Barton, M. D., (2006). Antimicrobial resistance in bacteria isolated from aquaculture sources in Australia. Journal of Applied Microbiology 100, 1103-1113.

Andersen, S. R., Saadbye, P., Shukri, N. M., Rosenquist, H., Nielsen, N. L. and Boel, J. (2006). Antimicrobial resistance among Campylobacter jejuni isolated from raw poultry meat at retail level in Denmark. International Journal of Food Microbiology 107, 250-255.

Berrang, M. E., Northcutt, J. K. and Cason, J. A. (2004). Recovery of Campylobacter from broiler feces during extended storage of transport cages. Poultry Science. 83, 1213-1217.

Caballero, A. T., Carrera, J. A. V. and Lengomin, M. E. F. (1998). Evaluacion de la vigilancia microbiologica de alimentos que se venden en las 
calles. Revista Cubana de Alimentacion ye de Nutricion 12, 7-10.

Clinical and Institute Laboratory Standards (CLSI) (2014). Performance standards for antimicrobial disc susceptibility tests; Approved Standard-11th Ed, M2A9. Wayne, PA, USA.

Cogan, T. A., Slader, J., Bloomfield, S. F. and Humphrey, T. J. (2002). Achieving hygiene in the domestic kitchen: The effectiveness of commonly used cleaning procedures. Journal of Applied Microbiology 92, 885-892.

De Boer, E. and Hahne, M. (1990). Crosscontamination with Campylobacter jejuni and Salmonella spp. from raw chicken products during food preparation. Journal of Food Protection 53, 1067-1068.

Denis, M., Refrégier-petton, J., Laisney, M. J., Ermel, G. and Salvat, G. (2001). Campylobacter contamination in French chicken production from farm to consumers. Use of a PCR assay for detection and identification of Campylobacter jejuni and C. coli. Journal of Applied Microbiology 91, 255267.

Denis, M., Tanguy, M., Chidaine, B., Laisney, M. J., Mégraud, F. and Pravalo, P. (2011). Description and sources of contamination by Campylobacter spp. of river water destined for human consumption in Brittany, France. Pathology and Biology 59, 256263.

Englen, M. D., Hill, A. E., Dargatz, D. A., Ladely, S. R. and Fedorka-Cray, P. J. (2007). Prevalence and antimicrobial resistance of Campylobacter in US dairy cattle. Journal of Applied Microbiology 102, 1570-1577.

European Food Safety Authority (EFSA), (2009). Joint opinion on antimicrobial resistance (AMR) focused on zoonotic infections. European Food Safety Authority Journal 7, 1372.

Evans, J. A., Russell, S. L., James C. and Corry, J. E. L. (2004). Microbial contamination of food refrigeration equipment. Journal of Food Engineering 62, 225-232.

Frediani-Wolf, V. and Stephan, R. (2003). Resistance patterns of Campylobacter spp. strains isolated from poultry carcasses in a big Swiss poultry slaughterhouse. International Journal of Food Microbiology 89, 233-240.

Friedman, C. R., Hoekstra, R. M., Samuel, M., Marcus, R., Bender, J., Shiferaw, B. and Tauxe, R. V. (2004). Risk factors for sporadic Campylobacter infection in the United States: A case-control study in FoodNet sites. Clinical Infectious Disease 38, S285S296.

Goni, M. D., Abdul-Aziz, S., Dhaliwal, G. K., Zunita, Z., Bitrus, A. A., Jalo, I. M., Aung, W. W., Mohamed, M. A. and Aliyu, A. B. (2017). Occurrence of Campylobacter in dogs and cats in Selangor Malaysia and the associated risk factors. Malaysian Journal of Microbiology 13, 164-171.
Gonzalez, I., Grant, K. A., Richardson, P. T., Park, S. F. and Collins, M. D. (1997). Specific identification of the entheropathogens Campylobacter jejuni and Campylobacter coli using a PCR test based on the ceuE gene encoding a putative virulence determinant. Journal of Clinical Microbiology 35, 759-763.

Health Action International Asia Pacifid (HAIAP) Third World Network (TWN) Penang in association with Consumers' Association of Penang. (2013). Antibiotic use and antibiotic resistance in food animals in Malaysia: A threat to human and animal Health. Page 5-7. http://www.haiasiapacific.org/wp-content/uploads/20 14/06/Memo-on-Antibiotics-in-animal-feeds-the-case -for-Malaysia-21-Nov-2013-V1.pdf (Accessed date $20^{\text {th }}$ December, 2017)

Herman, L., Heyndrickx, M., Grijspeerdt, K., Vandekerchove, D., Rollier, I. and De Zutter, L. (2003). Routes for Campylobacter contamination of poultry meat: Epidemiological study from hatchery to slaughterhouse. Epidemiology and Infection 131, 1169-1180.

Hong, J., Kim, J. M., Jung, W. K., Kim, S. H., Bae, W., Koo, H. C. and Park, Y. H., (2007). Prevalence and antibiotic resistance of Campylobacter spp. isolated from chicken meat, pork, and beef in Korea, from 2001 to 2006. Journal of Food Protection 70, 860866.

Huang, J. L., Xu, H. Y., Bao, G. Y., Zhou, X. H., Ji, D. J., Zhang, G., Liu, P. H., Jiang, F., Pan, Z. M., Liu, X. F. and Jiao, X. A. (2009). Epidemiological surveillance of Campylobacter jejuni in chicken, dairy cattle and diarrhoea patients. Epidemiology and infection 137, 1111-1120.

Hussain, I., Mahmood, M. S., Akhtar, M. and Khan, A., (2007). Prevalence of Campylobacter species in meat, milk and other food commodities in Pakistan. Food microbiology 24, 219-222.

Jacobs-Reitsma, W. F. (1997). Aspects of Epidemiology of Campylobacter in poultry. Veterinary Quarterly 19, 113 - 117. I.F.S.T., 1999. Organic food. International Food Safety News 8, 2-6.

Klena, J. D., Parker, C. T., Knibb, K., Ibbitt, J. C., Devane, P. M., Horn, S. T., Miller, W. G. and Konkel, M. E. (2004). Differentiation of Campylobacter coli, Campylobacter jejuni, Campylobacter lari, and Campylobacter upsaliensis by a multiplex PCR developed from the nucleotide sequence of the lipid A gene IpxA. Journal of Clinical Microbiology 42, 5549-5557.

Kusumaningrum, H. D., van Asselt, E. D., Beumer, R. R. and Zwietering, M. H. (2004). A quantitative analysis of cross-contamination of Salmonella and Campylobacter spp. via domestic kitchen surfaces. Journal of Food Protection 67, 1892-1903.

Le Roux, E. and Lastovica, A. J. (1998). The Cape Town Protocol: How to isolate the most Campylobacters for your dollar, pound, frank, yen, etc. In: Campylobacter, Helicobacter and Related 
Organisms. Lastovica, A. J., Newell, D. G., and Lastovica, E. E. (eds). pp 30-33. Institute of Child Helath, Univ. of Cape Town, Rondebosch: Cape Town, South Africa.

Linton, D., Owen, R. and Stanley, J. (1996). Rapid identification by PCR of the genus Campylobacter and of five Campylobacter species enteropathogenic for man and animals. Research in Microbiology 147, 707-718.

Little, C. L., Richardson, J. F., Owen, R. J., De Pinna, E. and Threlfall, E. J. (2008). Campylobacter and Salmonella in raw red meats in the United Kingdom: Prevalence, characterization and antimicrobial resistance pattern, 2003-2005. Food Microbiology 25, 538-543.

Lues, J. F. R. and Van Tonder, I. (2007). The occurrence of indicator bacteria on hands and aprons of food handlers in delicatessen sections of a retail group. Food Control 18, 326-332.

Luo, N., Pereira, S., Sahin, O., Lin, J., Huang, S., Michel, L. and Zhang, Q., (2005). Enhanced in vivo fitness of fluoroquinolone-resistant Campylobacter jejuni in the absence of antibiotic selection pressure. Proceedings of the National Academy of Sciences of the United States of America 102, 541-546.

Meldrum, R. J. and Wilson, I. G. (2007). Salmonella and Campylobacter in United Kingdom retail raw chicken in 2005. Journal of Food Protection 70, 1937-1939.

Mensah, P., Yeboah-Manu, D., Owusu-Darko, K., Ablordey, A., (2000). Street foods in Accra, Ghana: How safe are they? Bulletin of the World Health Organization 80, 1-14.

Miflin, J. K., Templeton, J. M. and Blackall, P. J. (2007). Antibiotic resistance in Campylobacter jejuni and Campylobacter coli isolated from poultry in the South-East Queensland region. Journal of Antimicrobial and Chemotherapy 59, 775-778.

Moore, J. E., Wilson, T. S., Wareing, D. R., Humphrey, T. J. and Murphy, P. G. (2002). Prevalence of thermophilic Campylobacter spp. in ready-to-eat foods and raw poultry in Northern Ireland. Journal of Food Protection 65, 1326-1328.

Nauta, M., Hill, A., Rosenquist, H., Brynestad, S., Fetsch, A., van der Logt, P. and Havelaar, A., (2009). A comparison of risk assessments on Campylobacter in broiler meat. International Journal of Food Microbiology. 129, 107-123.

OIE, (2015). List of antimicrobial agents of veterinary importance. http://www.oie.int/fileadmin/Home/eng/ Our_scientific_expertise/docs/pdf/Eng_OIE_List_anti microbials May 2015.pdf

Olah, P. A., Doetkott, C., Fakhr, M. K. and Logue, C. M. (2006). Prevalence of the Campylobacter multidrug efflux pump (CmeABC) in Campylobacter spp. isolated from freshly processed turkeys. Food Microbiology 23, 453-460.

Oliver, S. P., Murinda, S. E. and Jayarao, B. M. (2011). Impact of antibiotic use in adult dairy cows on antimicrobial resistance of veterinary and human pathogens: A comprehensive review. Foodborne Pathogen and Disease 8, 337-355.

Price, L. B., Johnson, E., Vailes, R. and Silbergeld, E. (2005). Fluoroquinolone-resistant Campylobacter isolates from conventional and antibiotic-free chicken products. Environmental Health Perspective 113(5), 557-560.

Rodrigo, S., Adesiyun, A., Asgarali, Z. and Swanston, W., (2007). Antimicrobial resistance of Campylobacter spp. isolated from broilers in small poultry processing operations in Trinidad. Food Control 18, 321-325.

Rosenquist, H., Nielsen, N. L., Sommer, H. M., Nørrung, B. and Christensen, B. B. (2003). Quantitative risk assessment of human campylobacteriosis associated with thermophilic Campylobacter species in chickens. International Journal of Food Microbiology 83, 87-103.

Rozynek, E., Dzierzanowska-Fangrat, K., Korsak, D., Konieczny, P., Wardak, S., Szych, J., Jarosz, M. and Dzierzanowska, D. (2008). Comparison of antimicrobial resistance of Campylobacter jejuni and Campylobacter coli isolated from humans and chicken carcasses in Poland. Journal of Food Protection. 71, 602-607.

Saénz, Y., Zarazaga, M., Lantero, M., Gastanãres, M. J., Baquero, F., Torres, C., (2000). Antimicrobial resistance in Campylobacter strains isolated from animals, foods, and humans in Spain in 1997 1998. Antimicrobial Agents and Chemotherapy 44, $267-271$.

Saleha, A. A. (2002). Isolation and characterization of Campylobacter jejuni from broiler chickens in Malaysia. International Journal of Poultry Science 1, 94-97.

Sallam, K. I. (2007). Prevalence of Campylobacter in chicken and chicken by-products retailed in Sapporo area, Hokkaido, Japan. Food Control 18, 1113-1120.

Smerdon, W. J., Adak, G. K., O'Brien, S. J., Gillespie, I. A. and Reacher, M. (2001). General outbreaks of infectious intestinal disease linked with red meat, England and Wales, 1992-1999. Communical Disease and Public Health 4, 259-267.

Sneed, J., Strohbehn, C., Gilmore, S. A. and Mendonca, A. (2004). Microbiological evaluation of foodservice contact surfaces in lowa assisted-living facilities. Journal of the American Dietetic Association 104, 1722-1724.

Stoyanchev, T., Vashin, I., Ring, C. and Atanassova, V. (2007). Prevalence of Campylobacter spp. in poultry and poultry products for sale on the Bulgarian retail market. Antonie van Leeuwenhoek 92, 285288.

Tambur, Z., Stojanov, I., Konstantinovic, S., Jovanovic, D., Cenic-Milosevic, D. and Opacic, D. (2010). Multidrug resistance of Campylobacter jejuni and Campylobacter coli to tested antibiotics in strains originating from humans, poultry and swine. Zbornik Matice Srpske Zaprirodne Nauke 118, $27-$ 35. 
Tang, J. Y. H., Mohamad Ghazali, F., Saleha, A. A., Nishibuchi, M. and Son, R. (2009). Camparison of thermophilic Campylobacter spp. occurrence in two types of retail chicken samples. International Food Research Journal 16, 277-288.

Uaboi-Egbenni, P. O., Bessong, P. O., Samie, A. and Obi, C. L. (2012). Potentially pathogenic Campylobacter species among farm animals in rural areas of Limpopo province, South Africa: A case study of chickens and cattles. African Journal of Microbiology Research 6, 2835-2843.

Wang, G., Clark, C. G., Taylor, T. M., Pucknell, C., Barton, C., Price, L. and Rodgers, F. G. (2002). Colony multiplex PCR assay for identification and differentiation of Campylobacter jejuni, C. coli, C. lari, C. upsaliensis, and C. fetus subsp. fetus. Journal of Clinical Microbiology 40, 4744-4747.

Yamazaki-Matsune, W., Taguchi, M., Seto, K., Kawahara, R., Kawatsu, K., Kumeda, Y., Kitazato, M., Nukina, M., Misawa, N. and Tsukamoto, T. (2007). Development of a multiplex PCR assay for identification of Campylobacter coli, Campylobacter fetus, Campylobacter hyointestinalis subsp. Hyointestinalis, Campylobacter jejuni, Campylobacter lari and Campylobacter upsaliensis. Journal of Medical Microbiology 56, 1467-1473.

Young, K. T., Davis, L. M. and DiRita V. J. (2007). Campylobacter jejuni: Molecular biology and pathogenesis. Nature Reviews 5, 665-679.

Zoran, T., Biljana, M. S., Radoje, D. and Zoran, K. (2010). Susceptibility of Campylobacter jejuni and Campylobacter coli isolated from animals and humans to tetracycline. African Journal of Microbiology Research. 4, 1246-1250. 